\title{
Comparison eugenol and oleic acid as a plasticizer on characteristic of dextromethorphan hydrobromide film by solvent casting method
}

\section{Nining Nining*, \\ Rahmah Elfiyani, \\ Elvira Wulandari}

Faculty of Pharmacy and Science, Universitas Muhammadiyah Prof. DR. HAMKA, Jakarta, Indonesia

*Corresponding author:

Nining Nining

nining@uhamka.ac.id

KEYWORDS:

Eugenol; Oleic acid; Plasticizer;

Dextromethorphan hydrobromide; Film

https://www.pharmacy.mahidol.ac.th/journal/ (C) Faculty of Pharmacy, Mahidol University (Thailand) 2021

\begin{abstract}
Dextromethorphan hydrobromide (DH) is a cough suppressing drug as strongly as codeine but lasts longer. Orally dissolving film (ODF) from combination pomelo skin pectin and chitosan is strong but stiff. Formulation of the film added oleic acid and eugenol as a plasticizer was to improve tensile strength and elongation. This study aimed to compare the influences of plasticizer usage against the characteristics of DH film. Pectin of pomelo skin was extracted using the reflux method. Organoleptic properties, identification test, ash content, moisture content, equivalent weight, and methoxyl content was evaluated characteristic of pectin. DH film was produced using oleic acid (DHF-oleic acid) and eugenol (DHF-eugenol) on a concentration of $2 \%, 4 \%$, and $6 \%$. Organoleptic properties, uniformity weight, thickness, tensile strength, percent elongation, $\mathrm{pH}$, disintegration time, determination level, and uniformity level was evaluated of film characteristic. The result of this study indicated that pectin characteristic conforms to requirements of high methoxyl form i.e., $7.43 \%$. Evaluation results for both films showed organoleptic properties, uniformity weight, thickness, $\mathrm{pH}$, and disintegration time have a similarity. Whereas tensile strength and percent elongation properties, DHF-eugenol has significantly different than DHF-oleic acid. In conclusion, eugenol as a plasticizer produced better film characteristics than oleic acid at all various concentrations on DH film.
\end{abstract}

\section{INTRODUCTION}

Fast dissolving drug system is one type of drug delivery that is starting to be widely accepted due to rapid disintegration and self-administration ${ }^{1}$. ODF is a film of $1-20 \mathrm{~cm}^{2}$ which contains dispersed drugs in polymeric matrices as a platform ${ }^{1,2}$. This film can increase drug onset, reduce the frequency of drug administration, and increase efficacy ${ }^{2}$.

Polymeric matrices used in this study are a combination of pectin from pomelo skin with chitosan. Pectin extraction is carried out under acidic conditions in order to obtain a type of high methoxyl content or referred to as high methoxyl pectin (HMP) $)^{3}$. HMP require a minimum amount of soluble solids 
(55\% to $80 \%)$ and a low $\mathrm{pH}(2.5$ to 3.5$)$ to form gels $^{4}$. Under normal circumstances, pectin and chitosan react readily to produce a polymer. The reaction between the polycations of chitosan and the polyanions of pectin leads to the formation of a polyelectrolyte complex (PEC) $)^{5}$. Various composite materials have been created from the interaction of the positively charged chitosan and negatively charged pectin ${ }^{6}$. The carboxyl group that gives a negative charge to the pectin will interact ionically with the chitosan amino group to form PEC, and reduce the amount of free remaining amino groups in solution.

Plasticizers reduce the glass transition temperature of polymer so that it can improve the workability, spreadability, and flexibility of the film? One of the plasticizers that could be used is vegetable oils. Usage of plasticizers in formulations consideration has been reported as an important factor affecting the mechanical properties of films ${ }^{1}$. Vegetable oils selected in this study were eugenol and oleic acid. In the manufacture of sodium caseinate film, the addition of oleic acid, pure or mixed with beeswax, creates a plasticizing effect in the film, increases elasticity, flexibility and percent elongation, and decreases water vapor permeability ${ }^{8}$. Another research, however, found that clove oil containing eugenol usage as a plasticizer on PVC membranes can increase surface hydrophilicity and elongation to break the film ${ }^{9}$. Considering the properties of eugenol and oleic acid, the attempt was made to develop fast dissolving films that have good mechanical properties without increasing disintegration time.

This study aimed to compare the usage of eugenol and oleic acid as a plasticizer in the same concentration $(2 \%, 4 \%$, and $6 \%)$ by the solvent casting method. Moreover, the effect of additional eugenol and oleic acid in the formula was evaluated using several parameters such as organoleptic properties, uniformity weight, thickness, $\mathrm{pH}$, disintegration time, tensile strength, and elongation percent.

\section{MATERIALS AND METHODS}

\subsection{Materials}

DH (Divi's Laboratories, India), pomelo skin powder (BALITTRO, Bogor, Indonesia), chitosan (Monodon group), acetic acid (PT. Putra
Primajaya), oleic acid and eugenol (Sigma-Aldrich), sucrose (Cap-Bintang Indonesia), menthol (PT. Samiraschem), ethanol (PT. Molindo Raya Industrial), methylparaben and propylparaben (Ueno-Japan).

\subsection{Pectin extraction from pomelo skin ${ }^{10}$}

In preparing pectin, $25 \mathrm{~g}$ of pomelo skin powder was added to $250 \mathrm{~mL}$ water and $10 \mathrm{~mL}$ $\mathrm{HCl} 1 \mathrm{~N}$ to reflux flask and heated at $80^{\circ} \mathrm{C}$ for $120 \mathrm{~min}$. The extract solution was filtrated by drab fabric into beaker glass. The filtrate was cooled and precipitated 1:1 with alcohol $96 \%$ for $24 \mathrm{~h}$. Precipitant was separated from the aqueous solution by filtration using filter paper and washed with alcohol $96 \%$ to remove residual acid. Pectin gel was dried in an oven at $45^{\circ} \mathrm{C}$ for $8 \mathrm{~h}$ and weighed. The percentage of yield was determined from the weight ratio of pectin produced and dry raw material.

\subsection{Pectin characterization ${ }^{11}$}

\subsubsection{Organoleptic properties and identification test}

Organoleptic properties were observed senses. The identification procedure of the test was (1) A-1g pectin added $9 \mathrm{~mL}$ water and heated above steam until soluble, then replace the lost evaporation water. (2) A- 0.5 g pectin added $50 \mathrm{~mL}$ water and stirred until soluble. Solution added ethanol $\mathrm{P}$ in the same volume. (3) A-5 mL solution (0.5 in 50) was added $1 \mathrm{~mL} \mathrm{NaOH} 2 \mathrm{~N}$ and kept at room temperature for $15 \mathrm{~min}$. (4) The gel from the previous test was acidified with hydrochloric acid $3 \mathrm{~N}$. The solution was shake and precipitant formed, which become white and agglomerate when heated.

\subsubsection{Determination of moisture and ash contents}

The sample was weighed 1-2 $\mathrm{g}$ in bottles weigh that have previously heated at $105^{\circ} \mathrm{C}$ for $30 \mathrm{~min}$ and has been calibrated. Flatten the sample in the bottles weigh until the layers $5-10 \mathrm{~mm}$, dried in an oven (the lid was opened) at $105^{\circ} \mathrm{C}$ until fixed weight ${ }^{11}$. The ash content was evaluated using a furnace method with a temperature of $550^{\circ} \mathrm{C}^{12}$.

\subsubsection{Equivalent weight $(E W)$ and methoxyl content ${ }^{13}$}

A- $0.5 \mathrm{~g}$ of pectin, $5 \mathrm{~mL}$ ethanol $96 \%, 1 \mathrm{~g}$ 
$\mathrm{NaCl} 100 \mathrm{~mL}$ distilled water (free of $\mathrm{CO}_{2}$ ) and six drops phenolphthalein indicator was added. The mixture was titrated with $\mathrm{NaOH} 0.1 \mathrm{~N}$ until

$$
\text { Equivalent weight }=\frac{\text { weight pectin }(\mathrm{mg})}{\mathrm{mL} \mathrm{NaOH} \times \mathrm{N} \mathrm{NaOH}}
$$

A neutral solution from a determination of EW was added to $25 \mathrm{~mL} \mathrm{NaOH} 0.25 \mathrm{~N}$. The solution stirred and kept for $30 \mathrm{~min}$ in a closed turns into pale pink $(\mathrm{pH}$ 7.5) and persisted at least $30 \mathrm{sec}$. A neutral solution was used for the determination of methoxyl levels.

$$
\text { Methoxyl levels }(\%)=\frac{\mathrm{mL} \mathrm{NaOH} \times 31 \times \mathrm{N} \mathrm{NaOH} \times 100}{\text { weight sample }(\mathrm{mg})}
$$

\subsection{DH film preparation}

Table 1. Design formula of film DH.

\begin{tabular}{llcccccc}
\hline \multirow{2}{*}{ Materials } & \multirow{2}{*}{ Function } & \multicolumn{7}{c}{ Formula } \\
\cline { 3 - 7 } & F1 & F2 & F3 & F4 & F5 & F6 \\
\hline DH & API & $300 \mathrm{mg}$ & $300 \mathrm{mg}$ & $300 \mathrm{mg}$ & $300 \mathrm{mg}$ & $300 \mathrm{mg}$ & $300 \mathrm{mg}$ \\
Pectin & Film-forming & $5 \%$ & $5 \%$ & $5 \%$ & $5 \%$ & $5 \%$ & $5 \%$ \\
Chitosan & Film-forming & $5 \%$ & $5 \%$ & $5 \%$ & $5 \%$ & $5 \%$ & $5 \%$ \\
Oleic acid & Plasticizer & $2 \%$ & $4 \%$ & $6 \%$ & - & - & - \\
Eugenol & Plasticizer & - & - & - & $2 \%$ & $4 \%$ & $6 \%$ \\
Acetic acid & Solvent & $10 \mathrm{ml}$ & $10 \mathrm{ml}$ & $10 \mathrm{ml}$ & $10 \mathrm{ml}$ & $10 \mathrm{ml}$ & $10 \mathrm{ml}$ \\
Sucrose & Sweeter & $8 \%$ & $8 \%$ & $8 \%$ & $8 \%$ & $8 \%$ & $8 \%$ \\
Menthol & Flavors & $0,5 \%$ & $0,5 \%$ & $0,5 \%$ & $0,5 \%$ & $0,5 \%$ & $0,5 \%$ \\
Methylparaben & Preservative & $0,18 \%$ & $0,18 \%$ & $0,18 \%$ & $0,18 \%$ & $0,18 \%$ & $0,18 \%$ \\
Propylparaben & Preservative & $0,02 \%$ & $0,02 \%$ & $0,02 \%$ & $0,02 \%$ & $0,02 \%$ & $0,02 \%$ \\
Water ad & Solvent & $100 \mathrm{ml}$ & $100 \mathrm{ml}$ & $100 \mathrm{ml}$ & $100 \mathrm{ml}$ & $100 \mathrm{ml}$ & $100 \mathrm{ml}$ \\
\hline
\end{tabular}

Pectin was dissolved with hot distilled water, then stir until the clear gel was formed. The mixture was added chitosan and acetic acid $1 \%$ while stirring using magnetic stirrer at $40^{\circ} \mathrm{C}$ for $45 \mathrm{~min}$ then mixed with oleic acid until homogeneous (M1). DH was dissolved with cold water as a solvent (M2). Sucrose, methylparaben, and propylparaben were dissolved with hot distilled water (M3). M1, M2, and M3 were mixed until homogeneous and then added menthol which has dripped 2-3 drops of ethanol and distilled water until $100 \%$. The colloidal solution was poured and molded on glass mold $12 \times 20 \mathrm{~cm}$. Drying was done in the oven at $30-40^{\circ} \mathrm{C}$ for $24 \mathrm{~h}$, then removed from the mold and cut into pieces of $2 \times 2 \mathrm{~cm}$ sized. The above flask. Then, a solution was added again to $25 \mathrm{~mL}$ $\mathrm{HCl} 0.25 \mathrm{~N}$ and titrated with $\mathrm{NaOH} 0.1 \mathrm{~N}$ until the indicator turns into pale pink. 


\subsubsection{Tensile strength and elongation}

Tensile strength was measured using Strograph-R1 (Toyoseiki, Japan) with $100 \mathrm{~kg}$ of force. The film was cut with a Dumbbell ASTM-D1822-L Crosshead (speed of $25 \mathrm{~mm} / \mathrm{min}$ ). Elongation was measured until the film break. The result of the data was analyzed statistically.

\subsubsection{Determination of disintegrating time, $\mathrm{pH}$ and uniformity of level}

The film was placed amid in a petri dish (Ø $10 \mathrm{~cm}$ ) with $10 \mathrm{~mL}$ of distilled water. Time was recorded that film destroyed entirely become soft (resolved) $)^{14}$. $\mathrm{pH}$ was measured using $\mathrm{pH}$ meter (LaMotte) that is calibrated in advance using $\mathrm{pH}$ buffer 4 and 7 . The electrode was rinsed with distilled water and dried. $\mathrm{pH}$ measurements have been performed on the solution of a film before poured.

Determination and uniformity of level were measured using spectrophotometer ultraviolet (Shimadzu UV-1601) ${ }^{15}$. Standard solution with phosphate $\mathrm{pH} 6.8$ as solvent was prepared to determine of maximum wavelength and made the calibration curve of DH. For determination of level, 20 sheets of film dissolved with buffer phosphate $\mathrm{pH}$ 6.8. The solution was sonicated for $30 \mathrm{~min}$ and filtered. A-1 mL filtrate was diluted in a $10 \mathrm{~mL}$ measuring flask. Then, the absorbance was measured. For uniformity of level, 10 sheets of film dissolved one by one with buffer phosphate $\mathrm{pH} 6.8$ Solution was sonicated for $15 \mathrm{~min}$ and filtered. Then, the absorbance was measured.

\subsection{Statistically analysis}

Tensile strength and elongation data were analyzed using two-way ANOVA. The result of ANOVA was continued using the Tukey HSD test with a $95 \%$ confidence level $(\alpha=0.05)$.

\section{RESULTS AND DISCUSSION}

\subsection{Characterization of pectin from pomelo skin}

Pectin is successfully extracted from the skin of pomelo. The yield of extraction was $9.79 \%$. The use of hot acid solution in the extraction of pectin helps to disrupt the tissue and bond between the rhamnogalacturonan I (RG-I) side chain of pectin and xyloglan or between the RG-I and xylan side chains, and between cellulose and pectin through the galactant side chain ${ }^{3}$. These conditions help to release pectin until maximum extraction is obtained.

In organoleptic properties, the pectin was odorless and tasteless ${ }^{11}$. While in color and shape, pectin is white-yellowish powder. Pectin was tested to identification (Table 2) and determine its characteristics and to assess whether the pectin used is in accordance (Table 3). Ash content in pectin was $2.39 \%$. The lower ash content indicated higher quality of pectin because of inorganic and mineral content in a small amount. Loss on drying is used for the determination of all types of volatile and missing materials under certain conditions (temperature $105^{\circ} \mathrm{C}$ ). According to IPPA (2001), it is required that the drying rate is no more than $12 \%$. The result of this study was dried up $7.79 \%$.

Table 2. Result of the identification test.

\begin{tabular}{ll}
\hline Test & \multicolumn{1}{c}{ Result } \\
\hline 1. Stiff gel formed & $(+)$ stiff gel \\
2. A clear precipitate formed, such as gelatin & $(+)$ a clear gel precipitate \\
3. Gel or semi gel formed & $(+)$ semi gel \\
4. A precipitate formed, such as gelatin, colorless and & $(+)$ agglomerated colorless gel and become \\
spread, become white and agglomerate when heated white when heated
\end{tabular}

*Indonesian Pharmacopeia (2014) 
Table 3. Characterization of pectin from pomelo skin.

\begin{tabular}{lcc}
\hline \multicolumn{1}{c}{ Parameter } & Result & Specification $^{*}$ \\
\hline Ash content & $2.39 \%$ & Max $10 \%$ \\
Loss on drying & $7.79 \%$ & Max $12 \%$ \\
Equivalent weight & $770.58 \mathrm{mg}$ & $600-800 \mathrm{mg}$ \\
Methoxyl content & $7.43 \%$ & High: $>7.12 \%$ \\
& & Low: $<7.12 \%$ \\
\hline
\end{tabular}

* International Pectin Producers Association/IPPA (2001)

Table 4. Organoleptic properties of DH film.

\begin{tabular}{ccccc}
\hline \multirow{2}{*}{ Formula } & \multicolumn{4}{c}{ Organoleptic test } \\
\cline { 2 - 5 } & Color & Smell & Sticky & Taste \\
\hline 1 & Transparent yellowish & Typical oleic acid & No & Sweet \\
2 & Transparent yellowish & Typical oleic acid & No & Sweet \\
3 & Transparent yellowish & Typical oleic acid & No & Sweet \\
4 & Transparent yellowish & Typical eugenol & No & Sweet \\
5 & Transparent yellowish & Typical eugenol & No & Sweet \\
6 & Transparent yellowish & Typical eugenol & No & Sweet \\
\hline
\end{tabular}

Equivalent weight is a measure of the free galacturonic acid group content which is not esterified in the pectin molecular chain. This study showed the equivalent weight of pectin was $770.58 \mathrm{mg}$ that which conforms to the requirement of the IPPA standard which ranges from $600-800 \mathrm{mg}$. Factors that influence the equivalent weight of pectin is type of plant, quality of raw materials, methods and extraction processes ${ }^{13}$.

Methoxyl pectin levels have an important role in determining the functional properties of pectin solutions and can affect the structure and texture of pectin gel. Methoxyl content can be defined as the number of moles of ethanol contained in 100 moles of galacturonic acid. Based on its methoxyl content, pectin can be divided into two groups, namely high methoxyl-level pectin (HMP), and low methoxyl-level pectin (LMP). HMP has a minimum methoxyl content of $7.12 \%$, while LMP has a maximum methoxyl content of $7.12 \%$. The level of methoxyl obtained in this study was $7.43 \%$. Based on the IPPA, methoxyl content produced from the extraction of pomelo skin using $\mathrm{HCl}$ solvents showed that pectin was included in the high-methylated category which means it has high solubility in water.

\subsection{Preparation and evaluation of the film}

The difference type and concentration of plasticizer used do not affect the color, sticky and sweet taste. However, difference typical smell was produced attend plasticizer usage i.e. formula I to III have smelled typical of oleic acid, whereas formula IV to VI has a typical smell of eugenol. Deviation percent of weighing 20 films was collected, the formula I to VI meets the requirements of weights uniformity with an average of 204-234 mg were no more than two films that deviate higher than $7.5 \%$ and not one films that deviate more than $15 \%$.

Thickness increases along with an increasing concentration of plasticizer. Film thickness influenced by the concentration of plasticizer was added. The DHF-eugenol has a thickness of 0,25 mm i.e. highest. Whereas, the DHF-oleic acid has a thickness of $0,163 \mathrm{~mm}$ i.e. smallest. The concentration of oleic acid and eugenol will increase solution viscosity and film thickness. Sitompul et al. explained that the greater concentration of plasticizer will 
increase the thickness and total solids in a film so the thickness film will increase ${ }^{16}$.

Tensile strength DHF-eugenol, i.e. 31-38 $\mathrm{kg} / \mathrm{cm} 2$, greater than DHF-oleic acid that is 20$30 \mathrm{~kg} / \mathrm{cm}^{2}$. Figure 1. shows the tensile strength and elongation film measurement chart.

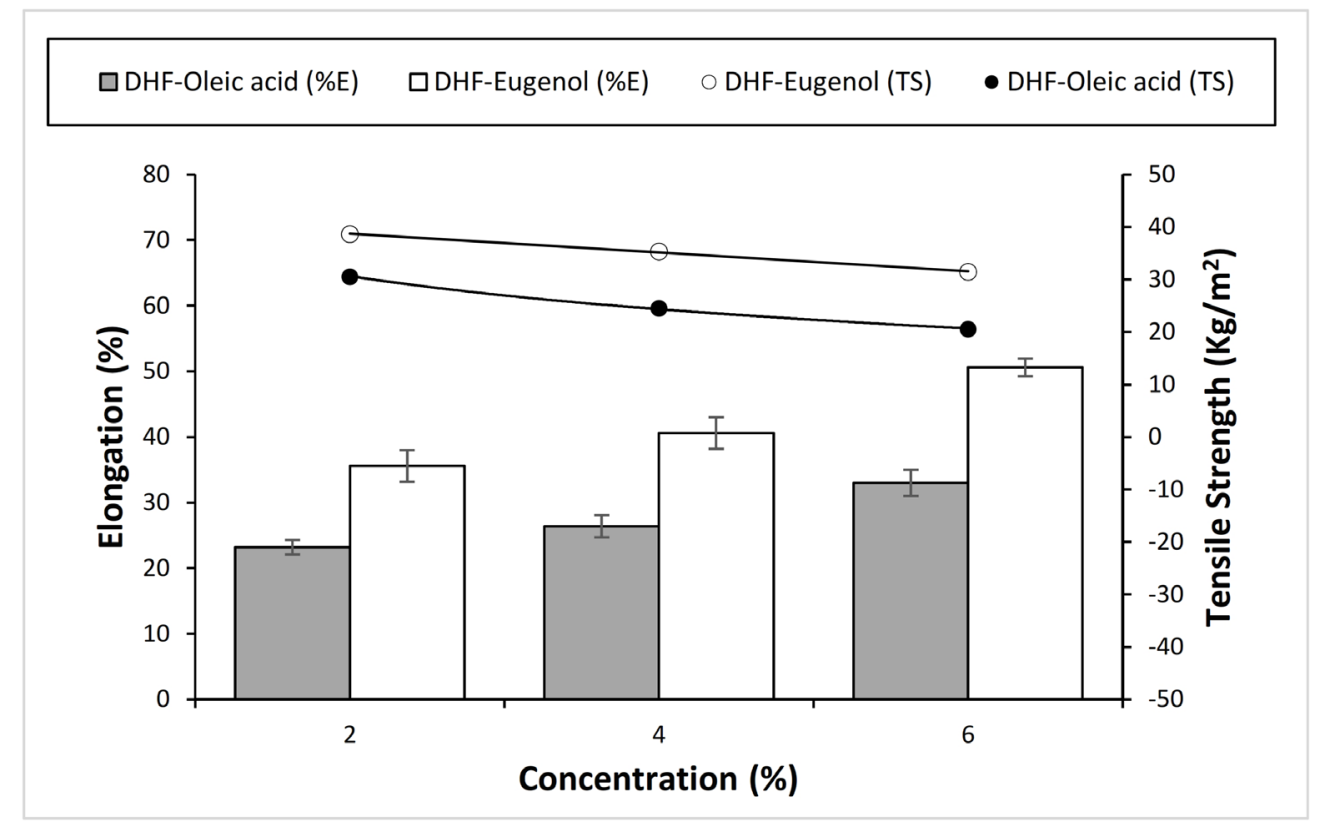

Figure 1. Tensile strength and elongation of DH films prepared from different type and concentration of plasticizer

From the chart, an increase in concentration plasticizer caused a decrease in tensile strength, by following the general properties of plasticizer usage. It is caused by the low water binding ability of eugenol in between polymer chain so that water is separated from polymer chain and limit its ability to lower hydrogen bonding between polymer chains compared with oleic acid ${ }^{16}$. Based on statistical analysis, tensile strength data shows that concentration interval $2 \%$ of oleic acid and eugenol as plasticizer produces significantly different tensile strength on DH film. Tensile strength measurements are usually followed by elongation measurement. DHF-eugenol has higher elongation i.e. $36-52 \%$ compared to DHFoleic acid that is $23-34 \%$. Plasticizer usage tended to tensile strength decreases and elongation increases because plasticizer can reduce the force between molecules and increase mobility chain biopolymers ${ }^{17}$. Based on statistical analysis, percent elongation shows that concentrations interval $2 \%$ of oleic acid and eugenol produce significantly different $\%$ elongation on DH film.
Addition of plasticizer improving the strength of matrix film and not easily disintegrated in water. The concentration of oleic acid and eugenol getting high can slow the disintegration time of the film. Disintegration time of DHF-oleic acid 2\% is $1 \mathrm{~min}$ 12 secs whereas disintegration time of DHF-eugenol $2 \%$ is $1 \mathrm{~min} 30 \mathrm{secs}$. Data results of disintegration time film range from 1-3 min. Disintegration time the DHF-oleic acid has destroyed faster than the DHF-eugenol. This occurs because oleic acid is more water-soluble than eugenol.

Solution $\mathrm{pH}$ of film from the sixth formula shows significant differences due to the presence of interactions between materials with the amount of plasticizer used. Oleic acid and eugenol have a different structure but the $\mathrm{pH}$ produced almost the same because ions $\mathrm{H}+$ in oleic acid and eugenol is not much different from the average $\mathrm{pH}$ 6,22$6,29 . \mathrm{pH}$ testing is crucial for oral preparations because if the $\mathrm{pH}$ is too high or low can irritate the mucosa of the mouth.

The maximum wavelength of $\mathrm{DH}$ was measured using a 40 ppm solution in $\mathrm{pH} 6.8$ of 
medium phosphate as solventusing spectrophotometer UV-Vis generated at $277.7 \mathrm{~nm}$ with 0.2590 absorptions. That number slightly different from different literature i.e. $278 \mathrm{~nm}^{18}$.

Calibration curve was created with four variance concentration i.e. $30,60,90$, and 120 ppm. Absorption value was 0,$248 ; 0,467 ; 0,673$; and 0,881 respectively. A linear regression equation obtained that $\mathrm{y}=0.0070+0,041 \mathrm{x}$ with correlation coefficient value is 0.9999 .

The percentage of DH on films was obtained that $96.80 \%, 91.42 \%, 83.16 \%, 86.99 \%, 94.24 \%$, and $92.68 \%$. These results do not conform to requirements on Indonesian Pharmacopoeia (2014), where DH contains not less than $98.0 \%$ and not more than $102.0 \%{ }^{11}$. This is can because at the manufacturing process any possibility the drug left on container or mold so that the resulting percentage of content is under requirements. Uniformity of content test on film was done. This is done because the dose of DH is $5 \mathrm{mg}$ in $250 \mathrm{mg}$ dosage weight. On formula I, SBR value is $1.88 \%$ where meet requirement Indonesian Pharmacopoeia i.e. SBR value for uniformity of content is less than $2 \%{ }^{11}$. Whereas on formula II-VI, SBR value exceeds requirements. The results suggested oleic acid could be potentially utilized as a plasticizer in formula film for a fast-dissolving drug delivery system.

\section{CONCLUSIONS}

DH film from pectin-chitosan plasticized with eugenol and oleic acid were prepared and characterized. Evaluation results for both films were observed. In conclusion, characteristic DHFeugenol as plasticizer better than characteristics DHF-oleic acid at various concentrations. The addition of oleic acid as a plasticizer in the formula for fast-dissolving films can produce films with good mechanical properties and meet the criteria.

\section{ACKNOWLEDGMENTS}

This research was supported by a grant from the University of Muhammadiyah Prof. DR. HAMKA, Indonesia.

\section{Conflict of interest (If any)}

None to declare.

\section{Funding}

None to declare

\section{Ethical approval}

None to declare

\section{Article info:}

Received February 19, 2020

Received in revised form May 6, 2020

Accepted May 28, 2020

\section{REFERENCES}

1. Bala R, Pawar P, Khanna S, Arora S. Orally dissolving strips: A new approach to oral drug delivery system. Int J Pharm Investig. 2013;3 (2):67-76.

2. Karki S, Kim H, Na SJ, Shin D, Jo K, Lee J. Thin films as an emerging platform for drug delivery. Asian J Pharm Sci. 2016;11(5):559-74.

3. Wandee Y, Uttapap D, Mischnick P. Yield and structural composition of pomelo peel pectins extracted under acidic and alkaline conditions. Food Hydrocoll. 2019;87(2):237-44.

4. Nieto MB. Structure and function of polysaccharide gum-based edible films and coatings. In: Embuscado ME, Huber KC, editors. Edible Films and Coatings for Food Applications. New York; Springer Sciences. 2009. p. 57-113.

5. Li W, Hao W, Xiaohua Z, Yinchen H, Wangwang L, Gongming Y, et al. Pectin-chitosan complex: Preparation and application in colon-specific capsule. Int J Agric Biol Eng. 2015;8(4):15160.

6. Chen PH, Kuo TY, Kuo JY, Tseng YP, Wang DM, Lai JY, et al. Novel chitosan-pectin composite membranes with enhanced strength, hydrophilicity and controllable disintegration. Carbohydr Polym. 2010;82(4):1236-42.

7. Irfan M, Rabel S, Bukhtar Q, Qadir MI, Jabeen F, Khan A. Orally disintegrating films: A modern expansion in drug delivery system. Saudi Pharm J. 2016;24(5):537-46.

8. Fabra MJ, Talens P, Chiralt A. Tensile properties and water vapor permeability of sodium caseinate films containing oleic acid-beeswax mixtures. J Food Eng. 2008;85(3):393-400.

9. Omer AM, Tamer TM, Monem AE, Elmoaty SA, Fatah MAE, Saad GR. Development of PVC membranes with clove oil as plasticizer 
for blood bag applications. J Appl Pharm Sci. 2016;6(7):85-93.

10. Sulihono A, Tarihoran B, Agustina TE. Pengaruh waktu, temperatur, dan jenis pelarut terhadap ekstraksi pektin dari kulit jeruk bali (Citrus maxima). J Tek Kim. 2012;18(4):1-8.

11. Indonesian Pharmacopoeia Commission. Farmakope Indonesia. Ed. V. Jakarta: Kementerian Kesehatan RI; 2014. p. 1003.

12. Association of Official Agricultural Chemists. Official methods of analysis: of AOAC International. 18th ed. Horwitz W, editor. Maryland: AOAC International; 2006. p. 1-96.

13. Wathoni N, Shan CY, Shan WY, Rostinawati T, Indradi RB, Pratiwi R, et al. Characterization and antioxidant activity of pectin from Indonesian mangosteen (Garcinia mangostana L.) rind. Heliyon. 2019;5(8):e02299.

14. Bhowmik D, Chiranjib B, Krishnakanth, Pankaj, Chandira RM. Fast dissolving tablet :
An Overview. 2009;1(1):163-77.

15. Kunwarpuriya A, Doke V, Patel D, Sangha S, Singh SR, Khutle NM. Formulation and evaluation of dextromethorphan hydrobromide fast dissolving film. Int J Innov Pharm Sci Res. 2015;3(8):998-1108.

16. Sitompul AJWS, Zubaidah E. The influence of the type and concentration of plasticizer toward the physical characteristic of edible film from palm fruit (Arenga pinnata). J Pangan dan Agroindustri. 2017;5(1):13-25.

17. McHugh TH, Krochta JM. Sorbitol-vs glycerolplasticized whey protein edible films: integrated oxygen permeability and tensile property evaluation. J Agric Food Chem. 1994;42(4): 841-5.

18. Dahiya J, Singh A, Gupta SK, Kumar B. Spectrophotometric estimation of dextromethorphan in bulk drug using hydrotropic solubilization technique. Asian J Pharm Ana. 2013;3(3):90-3. 